\title{
Temporal changes in the physicochemical, textural and sensory attributes of butter fortified with vegetarian source of omega-3 fatty acid
}

\author{
Vishal S Pandule ${ }^{1}$, Monika Sharma ${ }^{2}$, Devaraja $\mathrm{HC}^{2}$, Menon Rekha Ravindra ${ }^{2}$ and B Surendra Nath ${ }^{2}$
}

Received: 11 June 2021 / Accepted: 01 July 2021 / Published online: 07 September 2021

(c) Indian Dairy Association (India) 2021

\begin{abstract}
Fortification of butter with omega-3 fatty acids and alpha linolenic acid results in higher level of unsaturated fatty acids. This may affect the oxidative stability of butter. Therefore, the present study was conducted to evaluate the impact of storage on the physico-chemical, textural and sensory attributes of the fortified butter samples packed in polypropylene cups and stored at 5 and $-18^{\circ} \mathrm{C}$. The samples were analysed for 90 days with an interval of 15 days. During the storage, the samples were analysed for physico-chemical properties, oxidative stability, textural characteristics, sensory characteristics and microbial quality. Control sample showed higher $(4.35 \mathrm{~h})$ induction period than samples prepared by adding flaxseed oil $(2.36 \mathrm{~h})$ and flaxseed oil emulsion $(2.56 \mathrm{~h})$ as studied by rancimat. Peroxide value, free fatty acids and TBA value increased significantly $(\mathrm{P}<0.05)$ during storage however, the values were within the acceptable range. The optimized butter samples were examined for storage stability under refrigeration and frozen conditions for 90 days. Firmness, work of shear and yield stress increased slightly during the storage and samples stored at $-18^{\circ} \mathrm{C}$ showed higher values than refrigerated storage. Even though, overall sensory acceptability decreased significantly $(\mathrm{P}<0.05)$ during the storage and the samples stored at $-18^{\circ} \mathrm{C}$ showed higher score than refrigerated storage; it was still above 7.5 on 9 point hedonic scale. No microbial growth was observed throughout the storage period. Thus, it is concluded that omega-3 fatty acid fortification doesn't adversely affect the storage stability of fortified butter and the butter has good sensorial acceptability and oxidative stability for 90 days of storage period.
\end{abstract}

Keywords: Alpha linolenic acid, Fortification, Induction period, Omega-3 fatty acids, Storage stability,

\footnotetext{
${ }^{1}$ Hatsun Agro Product Ltd, Palacode-636808, Tamil Nadu, India

${ }^{2}$ ICAR- National Dairy Research Institute, SRS, Bengaluru, India
}

Monika Sharma $(\bowtie)$

ICAR- National Dairy Research Institute, SRS, Adugodi, Bengaluru560030

E-mail: Monika.Sharma@icar.gov.in, sharma.monikaft@gmail.com

\section{Introduction}

Butter is a fat rich dairy product and very good source of fat as well as fat soluble vitamins viz. A, E, K. However, it contains high level of cholesterol and saturated fats which can be a cause of health concern (Drouin et al. 2018). Further, butter also lacks in omega-3 fatty acids which are essential functional components. They help in improvement of eye health, prevention of cardiovascular diseases, lowers the risk of hypertension, coronary heart diseases (CHD), inflammatory bowel disease (IBD), neurodegenerative disorder, cancers and diabetes (Chen et al. 2013). Omega-3 fatty acids also exhibit anti-inflammatory (Mori et al. 2000) and hypocholesterolemic (Dawczynski et al. 2010) properties. The ratio of omega 6: omega 3 fatty acid is found to be very high to the level of 38-50:1 (Singh et al. $2011 \mathrm{a}, \mathrm{b}$ ) among the Indian urban population compared to the recommended level of 5:1 (FAO/WHO 2010). Thus, in order to bridge this huge gap between the actual and recommended level of omega-3 fatty acids in Indian diet, fortification of food products with omega-3 fatty acids is the ideal approach. Further, fat rich dairy products are compatible for the maximum fortification with omega-3 fatty acids with added flavourings (Kolanowski et al. 2007). Thus, butter, the second most consumed fat rich dairy product in the country, was selected for fortification with omega-3 fatty acids.

Fortification could be achieved through various sources of omega-3 fatty acids such as oily fishes which majorly contain eicosapentaenoic acid (EPA) and docosahexaenoic acid (DHA). But alpha-linolenic acid (ALA) is found in vegetarian source like flaxseeds, soybean oil, wheat germ oil, canola oil and nuts (Gruenwald et al. 2009, Mantzioris et al. 2000). Due to ethical issues related to the consumption of fish oil among the vegetarian population, flaxseed could become a vegetarian alternative as it contains higher unsaturated fatty acid. Lipids in the flaxseed comprise of $9 \%$ saturated fatty acid, $18 \%$ monounsaturated fatty acid and $73 \%$ polyunsaturated fatty acids (Brenna et al. 2009). Along with higher content of polyunsaturated fatty acid, flaxseed contains some antinutritional factors like cyanogenic glycosides about 250-550 mg/100g (Oomah and Mazza 1998). However, the anti-nutritional factors are not present in the flaxseed oil. Thus, flaxseed oil with higher ALA content is preferred for omega-3 fatty acids fortification of foods. But, the presence of nearly 75 
percent polyunsaturated fatty acids such as alpha-linolenic and linoleic fatty acids in flaxseed oil makes it more prone to the oxidation (Ramcharitar et al. 2005) and may result in toxic peroxides upon processing such as heat treatment. Thus, direct fortification of food and dairy products with flaxseed oil may results in products susceptible to oxidation which finally results in off flavour development. Further, flaxseed oil can be added in the form of emulsion for fortification purpose as it improves oxidative stability. The bioavailability of ALA has reported to be higher through emulsion than pills (McKenna and Kilcast 2003; Couedelo et al. 2011).

Pandule et al. (2021) fortified butter with alpha linolenic acid using flaxseed oil as well as flaxseed oil emulsion. The alpha linolenic acid has increased 3.7 times in fortified butter which can provide nearly $25 \%$ of the recommended dietary allowance in one serving. Apart from the increased content of alpha linolenic acid, fortification also improved the textural characteristics especially the spreadability of the developed butter. Alteration in fatty acid profile of the butter, may impact the physico-chemical properties of the butter such as peroxide value, free fatty acids (FFA), Thiobarbituric acid (TBA) value, pH, titratable acidity, spreadability particularly during its storage, which in turn would affect the shelf stability of the omega-3 fatty acid fortified butter. With this backdrop, the present study evaluates the oxidative stability, sensory acceptability and textural properties of the fortified butter during storage.

\section{Materials and Methods}

Flaxseed oil (cold pressed) gifted by AAK Kamani Pvt. Ltd. Andheri, Mumbai (Maharashtra). The cream and skim milk were collected from Experimental dairy of Southern Regional Station, ICAR-NDRI, Bangalore. Butter culture was obtained from National Collection of Dairy Cultures (NCDC), NDRI, Karnal. Whey protein concentrate (WPC) was procured from Sridurga Sales Corporation imported from Friesland Campina, Netherland.

\section{Methods}

\section{Preparation of flaxseed oil emulsion}

For preparing the flaxseed oil emulsion ( $60 \%$ oil load); firstly, the $40 \%$ aqueous phase was prepared by dissolving $7.5 \%$ WPC on the basis of total quantity of emulsion and later, to this calculated amount of oil was added. Emulsion was prepared by mixing with hand blender for 5 minutes and stored at refrigerated temperature $\left(4-7^{\circ} \mathrm{C}\right)$ for further use.

\section{Preparation of Alpha-linolenic acid fortified butter}

For the preparation of two variants of alpha-linolenic acid fortified butter, flaxseed oil and flaxseed oil emulsion were respectively, added into the cream before ageing (Pandule et al. 2021). The butter was packed in $250 \mathrm{~g}$ blocks in the polypropylene (PP) cups and stored at $5^{\circ} \mathrm{C}$ and $-18^{\circ} \mathrm{C}$ for analysis of various temporal changes.

\section{Water activity}

Water activity of the product was determined by using water activity meter (Aqua lab Model Series $3 \mathrm{TE}$ ), stabilized for $10 \mathrm{~min}$.

\section{Titratable acidity and pH of butter}

Titratable acidity and $\mathrm{pH}$ of butter was determined by method given in section 8.0 of IS: $3507-1966$ and section 9.2 of IS: $3507-$ 1966 , respectively.

\section{Induction period}

Induction period was measured by taking $2.5 \pm 0.05 \mathrm{~g}$ sample in Rancimat (Metrohm, Switzerland) reaction vessels where it was oxidised at $120 \pm 0.2^{\circ} \mathrm{C}$ by passing oxygen from the bottom of the samples according to the instructions given in the instruction manual of Metrohm Rancimat 679 (Metrohm 1993). The values are reported in hours.

\section{Peroxide value (PV) and Free fatty acids (FFA) value}

Peroxide value and FFA content were determined according to the Method Cd 8-53 of the AOAC (1993) and Kuruppu et al. (1983), respectively. The results were expressed in $\mathrm{mEq} \mathrm{O}_{2} / \mathrm{kg}$ of fat.

\section{Thiobarbituric acid (TBA) value}

TBA value was estimated according to method described by Kuruppu et al. (1983) with slight modification (without addition of BHA) and results were expressed in terms of $\mathrm{mM}$ Malonaldehyde (MDA)/kg of fat.

\section{Textural analysis of butter}

The samples were tempered to $24^{\circ} \mathrm{C}$ by keeping at room temperature for about $4 \mathrm{hrs}$ before analysing textural properties. Spreadability of the butter was determined by spreadability rig using TA-XT plus Texture Analyser. In case of creep test, $20 \mathrm{~mm}$ $\mathrm{X} 20 \mathrm{~mm}$ X $20 \mathrm{~mm}$ cubes were cut and tempered to $24^{\circ} \mathrm{C}$. Creep test was carried out by using P/75 Platen probe.

\section{Sensory evaluation of butter samples}

Butter samples were tempered for $15 \mathrm{~min}$ before sensory evaluation. The semi trained panellists ( 9 members) consisting of the staff and students of the Dairy Processing group of the institute, analysed the butter samples $\left(20-24^{\circ} \mathrm{C}\right)$ using 9-points hedonic scale. 


\section{Microbiological analysis}

Coliform count of the butter samples was determined by method section 13 of IS: 3507-1966. Also, yeast and mould count of the butter samples was determined by method given in section 14 of IS: 3507-1966.

\section{Determination of omega-3 fatty acid (ALA) content}

Fat extraction and preparation of fatty acid methyl esters (FAME)

The method of Pandule et al. (2021) was followed for fat extraction from butter and preparation of FAME.

Determination of fatty acid compositions by Gas Chromatography-Mass Spectrophotometry

DB5 MS ( $30 \mathrm{~m} \times 0.25 \mathrm{~mm} \times 0.25 \mu \mathrm{m})$ capillary column was used to separate FAME with helium as a carrier gas at a ûow rate of 1 $\mathrm{ml} / \mathrm{min}$. The injector temperature was $230^{\circ} \mathrm{C}$, and the column temperature was programmed as follows: $50^{\circ} \mathrm{C}$ in the beginning for $1 \mathrm{~min}$, subsequent increase to $220^{\circ} \mathrm{C}$ at the rate of $3^{\circ} \mathrm{C} / \mathrm{min}$ and maintained for $1 \mathrm{~min}$. In between; $2^{\circ} \mathrm{C} / \mathrm{min}$ rate was also followed from $40 \mathrm{~min}$ time till the end. The interface temperature for GC-MS (Agilent Technologies, Santa Clara, CA) was $220^{\circ} \mathrm{C}$. Tridecanoic acid was used as internal standard to quantify FAME. Identiûcation of fatty acids was made on the basis of mass spectral libraries (NIST 47, NIST 147 and Wiley 175), as well as data from literature and by comparison of their retention times with supalco-37 standards GLC-85 and FAME Mix GLC90.

\section{Results and Discussion}

Fortification of the butter with omega-3 fatty acid resulted in samples having $>80 \%$ fat, $<16 \%$ moisture and $<3 \%$ solids-notfat, thereby confirming the butter standards. The ALA content in the control and fortified butter samples was found to be $0.872 \%$, $3.149 \%$ (prepared using flaxseed oil) and $3.174 \%$ (prepared using emulsion), respectively as analysed using GC-MS. The fortification not only elevated omega-3 fatty acids content but also improved the spreadability in fortified butter (Pandule et al. 2021).

\section{Physico-chemical changes in fortified butter during storage}

Due to oxidation susceptible nature of unsaturated fatty acids, oxidation stability and physico-chemical properties of the fortified butter has been studied during storage. Apart from these, effect of storage period and temperature on spreadability along with the sensory acceptability and microbiological parameters is discusses in the following sections.

\section{Water activity of the control and fortified butter}

The significance of water activity is immense for governing the microbial growth as well as in controlling the rate of chemical reactions, thereby dictating the shelf life of the product. In the present investigation, the control $(0.9449)$ butter had higher water activity than fortified samples i.e. $4.1 \% \mathrm{OABA}(0.9074)$ and $6.8 \%$ EABA (0.9126). This may be due to entrapment of free water in the fortified butter during binding of oil molecules with protein. The lower water activity of fortified samples may help in preventing the microbial growth upon storage.

\section{Acidity of control and fortified butter during storage}

Acidity plays an important role in the shelf life of product. Storage at higher temperature leads to increase in the acidity. In the present study, control butter stored at $5^{\circ} \mathrm{C}$ showed significantly $(\mathrm{P}<0.05)$ higher acidity than the fortified samples $(4.1 \% \mathrm{OABA}$ and $6.8 \%$ EABA). The acidity of the samples stored at $5^{\circ} \mathrm{C}$ showed significant $(\mathrm{P}<0.05)$ increase in the acidity throughout the storage period (Figure 1a).

In case of samples stored at $-18^{\circ} \mathrm{C}$, there was slight but statistically significant $(\mathrm{P}<0.05)$ increase in the acidity of the butter throughout the storage period, in all the samples (Figure 1b). The control sample had higher acidity than the fortified butter. Similar results were also reported by Kulkarni and Rama Murthy (1985) for the increase in acidity of the butter during entire storage period. They reported that during first 6 months of storage, acidity of fat increased from 1.2 to $2.3 \%$ and then remained constant.

\section{pH of control and fortified butter during storage}

The $\mathrm{pH}$ is one of the contributing parameters indicating the storage life of the product as most of the microbial growth and chemical changes are $\mathrm{pH}$ dependent. The $\mathrm{pH}$ of the samples stored at $5^{\circ} \mathrm{C}$, decreased significantly $(\mathrm{P}<0.05)$ with the storage period (Figure 1c). This correlates well with the acidity results mentioned in previous section. The butter sample fortified with oil showed highest, while the control butter depicted lowest $\mathrm{pH}$ among the three samples when stored at $5^{\circ} \mathrm{C}$. Similar trend was found in butter stored at $-18^{\circ} \mathrm{C}$. There was significant $(\mathrm{P}<0.05)$ decrease in the $\mathrm{pH}$ of the butter with the increase in period of storage (Figure 1d). But storage at $-18^{\circ} \mathrm{C}$ showed lesser degree of change in the $\mathrm{pH}$ than at $5^{\circ} \mathrm{C}$.

\section{Oxidative stability of control and fortified butter}

\section{Induction period of control and fortified butter}

Induction period is the time taken up in an accelerated ageing method for the secondary reaction products to arise. Thus, it gives a basic idea about the oxidative stability of the product. In the present study, the control butter had higher induction period $(4.35 \mathrm{~h})$ than the fortified samples (Figure 2 a-c) i.e. $4.1 \% \mathrm{OABA}$ 


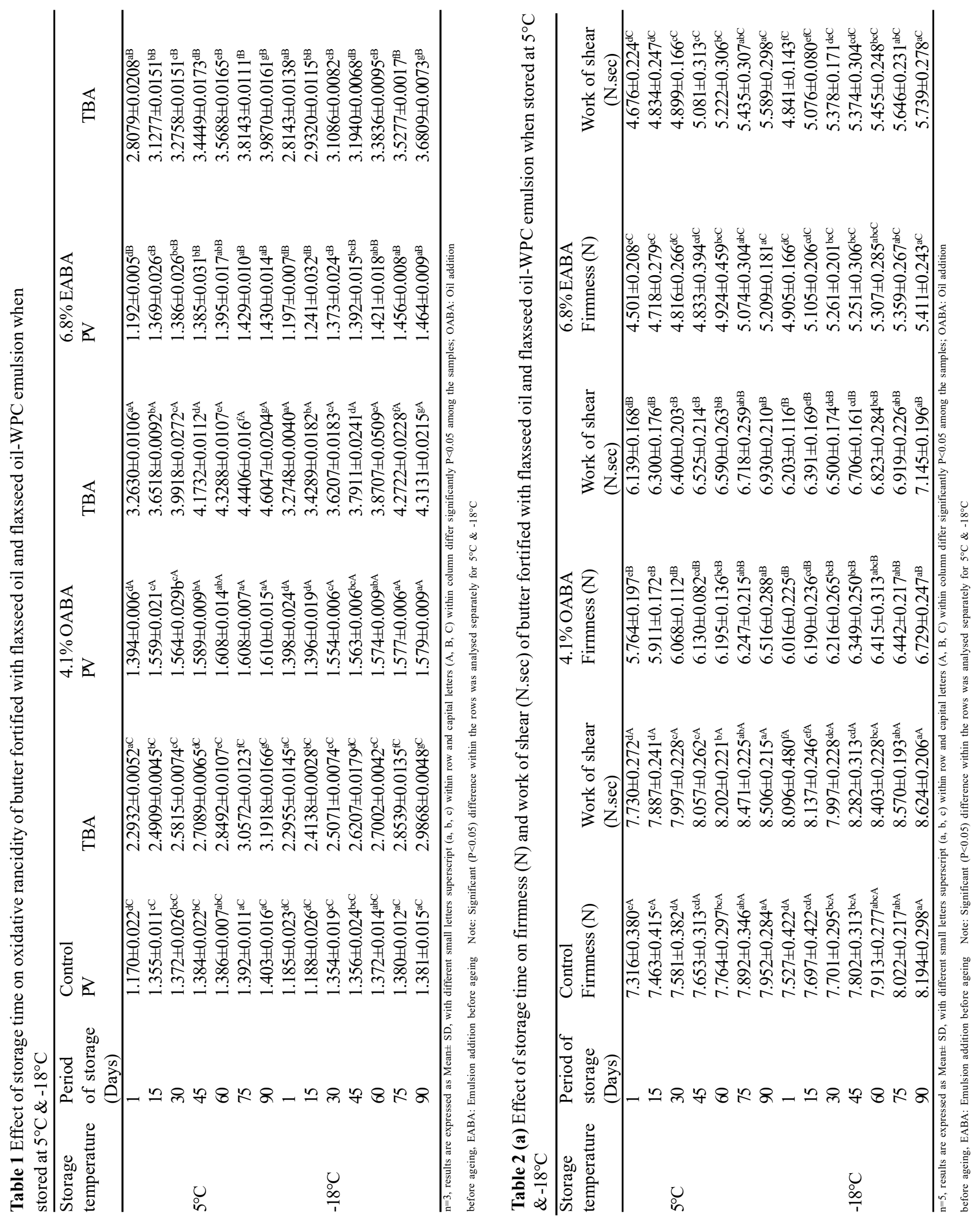



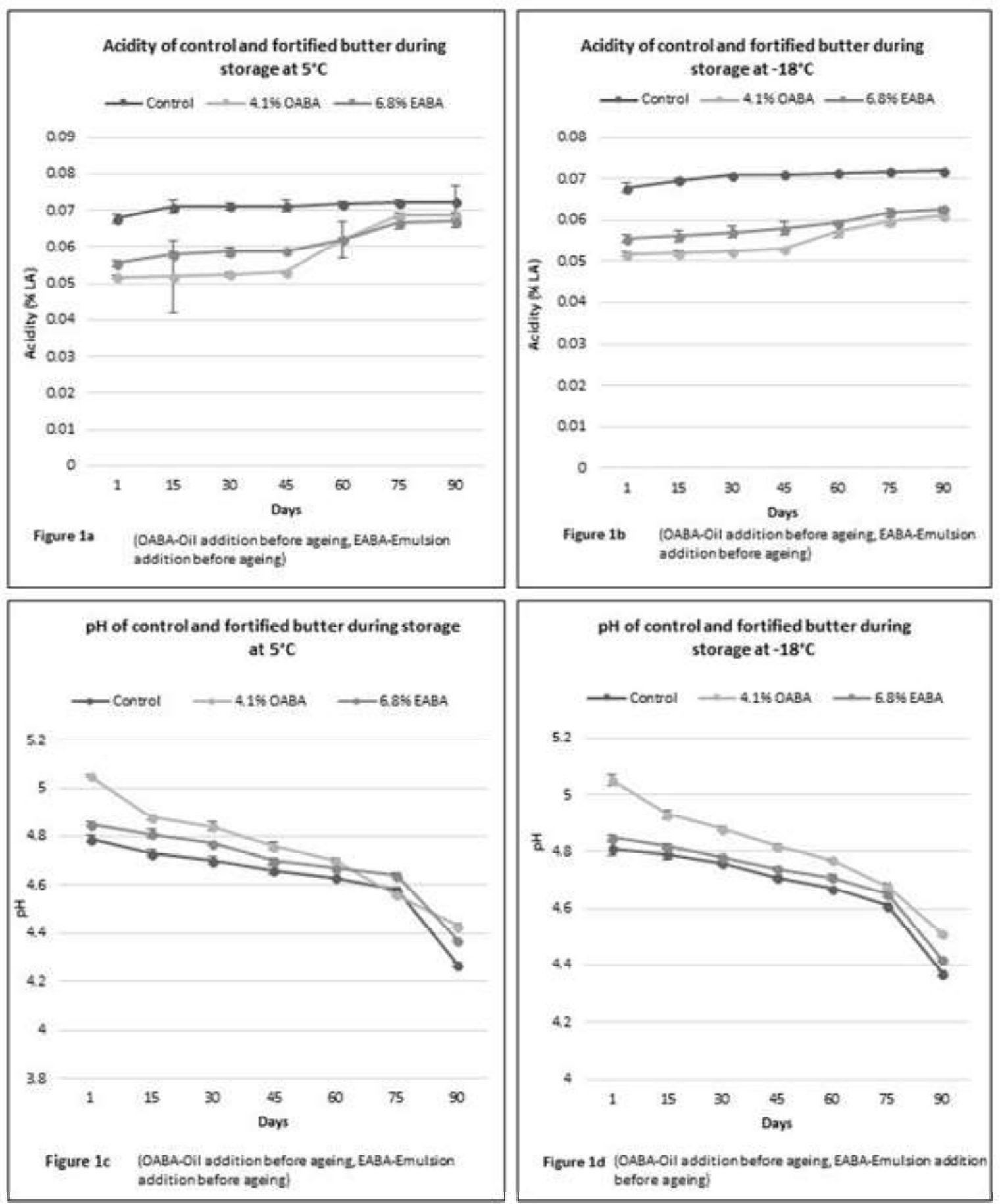

Fig. 1 Acidity (a-b) and $\mathrm{pH}(\mathrm{c}-\mathrm{d})$ of control and omega- 3 fatty acid fortified butter during storage at $(\mathrm{a}, \mathrm{c}) 5^{\circ} \mathrm{C}$ and (b,d) $-18^{\circ} \mathrm{C}$ for 90 days

$(2.36 \mathrm{~h})$ and $6.8 \% \operatorname{EABA}(2.56 \mathrm{~h})$. Decline in the induction period for fortified butter samples was due to the increase in unsaturated fatty acids which are more prone to the oxidation through fortification. Nadeem et al. (2013) observed the increase in the induction period $(8.91 \mathrm{~h})$ of butter containing Moringa oleifera leaf extract than the control butter $(6.35 \mathrm{~h})$ owing to the antioxidant potential of the Moringa oleifera leaf extract. The reason for higher induction period for the flaxseed oil emulsion fortified butter than the oil fortified butter sample could be attributed to the binding property of the residual WPC with the oil, thereby providing more oxidative stability to the fortified butter. The whey proteins have also been reported to exhibit radical scavenging activity (Corrochano et al. 2018). 


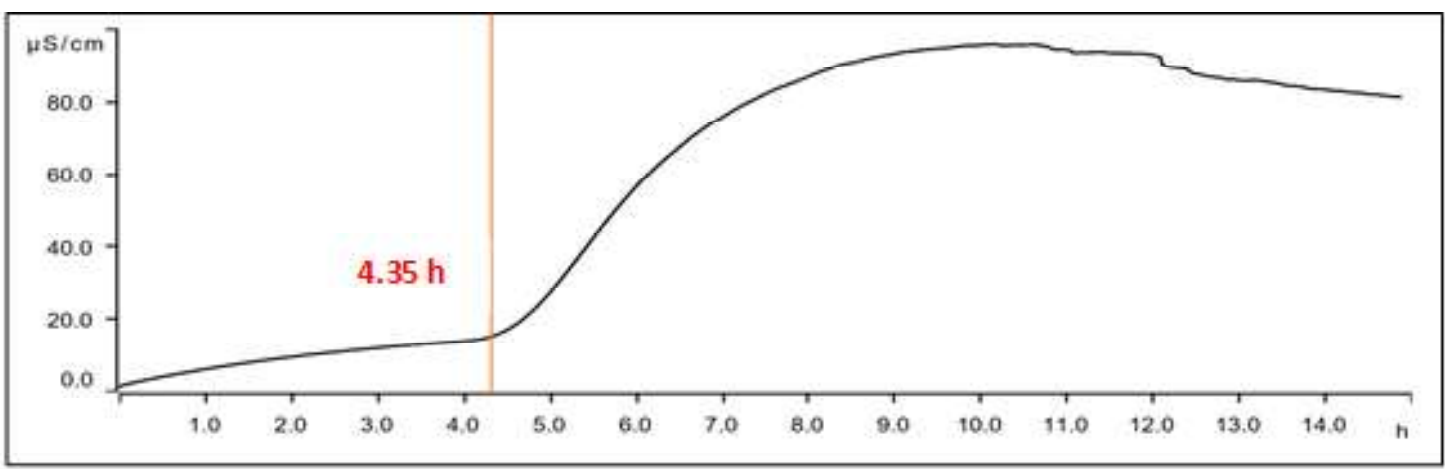

Figure 2a Induction period (using Rancimat) of control butter

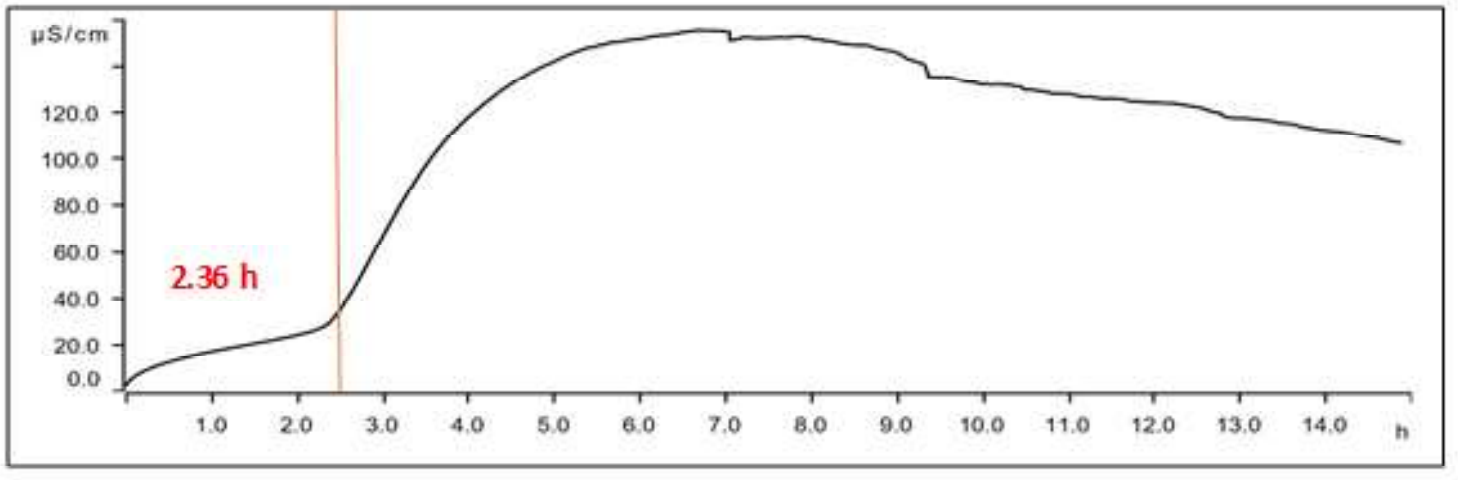

Figure $\mathbf{2 b}$ Induction period (using Rancimat) of butter prepared by adding flaxseed oil

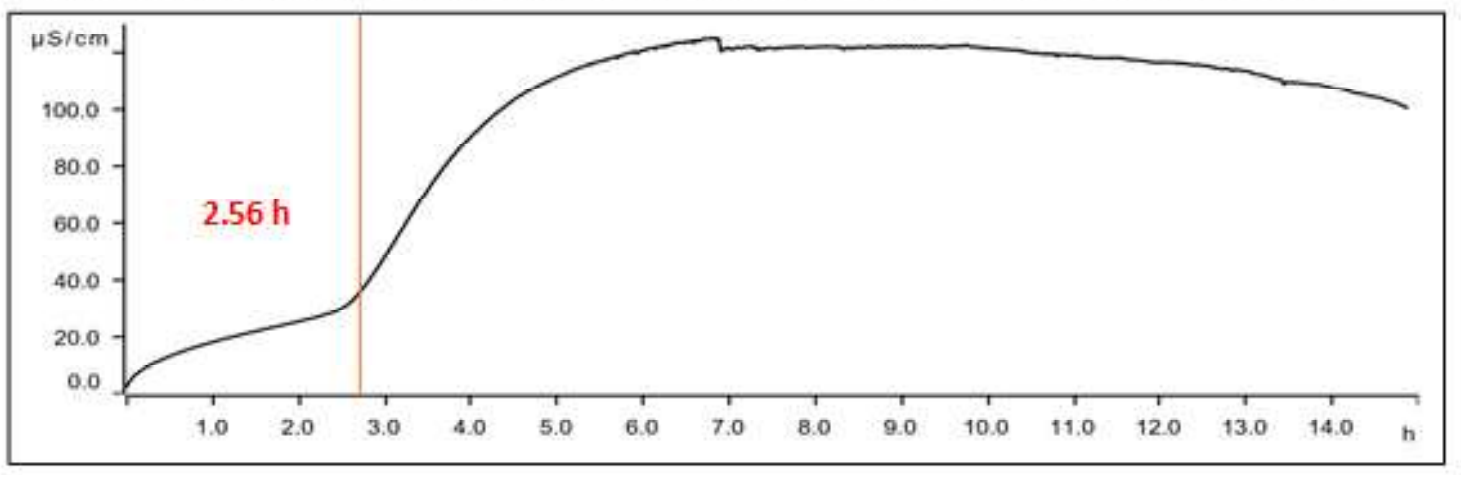

Figure $2 c$ induction period (using Rancimat) of butter prepared by adding flaxseed oil emulsion

Fig. 2 Induction period of (a) control butter, (b) fortified butter prepared by adding flaxseed oil and (c) fortified butter prepared by adding flaxseed oil-WPC emulsion

\section{Peroxide value (PV) of control and fortified butter during} storage

Peroxide value gives an idea about the initiation of the rancidity in the unsaturated fatty acid and it is the measure of autoxidation i.e. oxidative rancidity. In the present study, butter stored at $5^{\circ} \mathrm{C}$ showed increase in the peroxide value on $15^{\text {th }}$ day of storage and then increased significantly $(\mathrm{P}<0.05)$ throughout the storage period (Table 1). Among the three samples, control butter showed lowest peroxide value. The higher value for fortified samples is due to the presence of more unsaturated fatty acids. The butter prepared by adding flaxseed oil (4.1\% OABA) showed higher peroxide value than the control and sample prepared by adding emulsion (6.8\% EABA). These results are in agreement with the trend observed for induction period of these samples. This could be due to the protective role of emulsion towards oxidation due to the presence of WPC than direct flaxseed oil addition.

In case of fortified butter stored at $-18^{\circ} \mathrm{C}$, the rapid and significant $(\mathrm{P}<0.05)$ increase in the peroxide value was found till the $30^{\text {th }}$ day of storage and after that slight increase throughout the storage period in all the butter samples (Table 1). The control butter showed significantly $(\mathrm{P}<0.05)$ lower peroxide values than fortified butter and the sample 6.8\% EABA showed significantly $(\mathrm{P}<0.05)$ lower values than $4.1 \%$ OABA. Results of the Devdhara et al. 


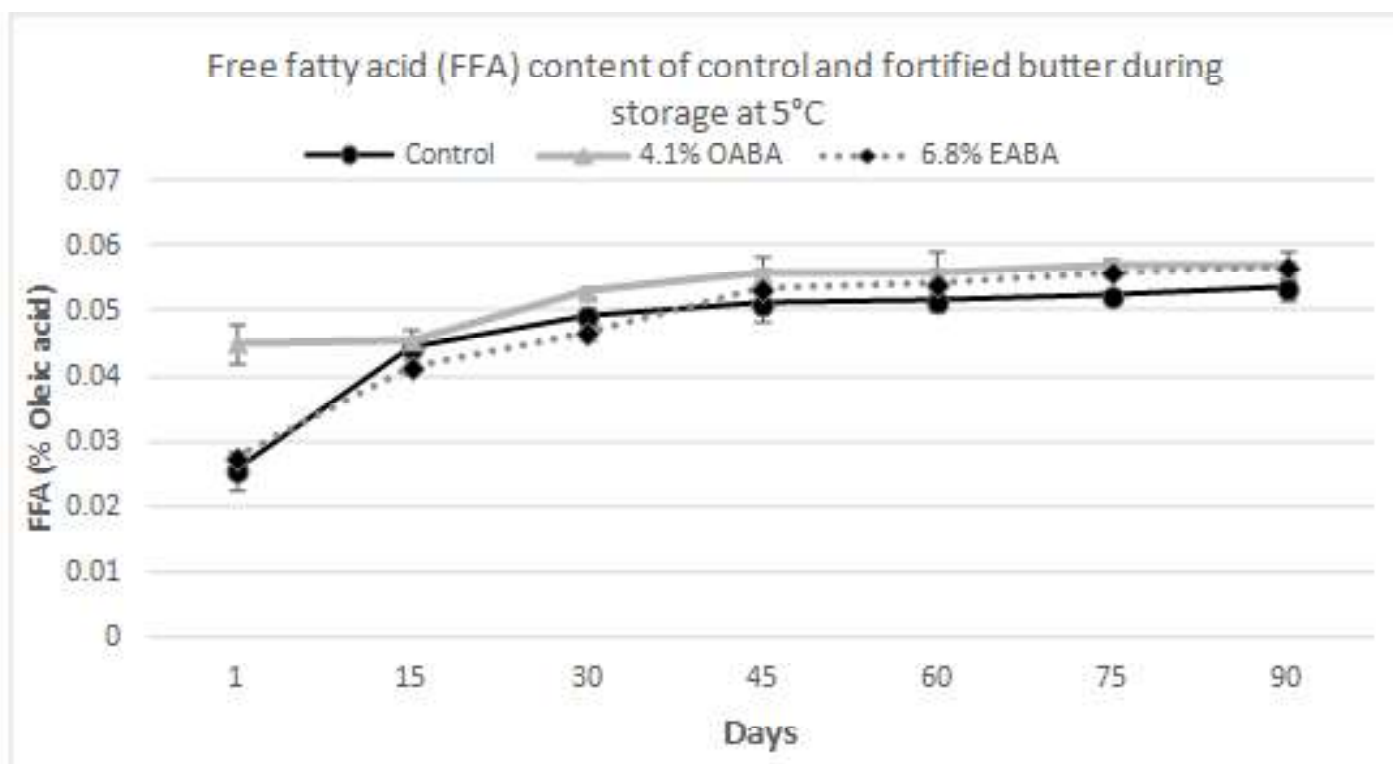

Figure 3a (OABA-Oiladdition before ageing, EABA-Emulsionaddition before ageing)

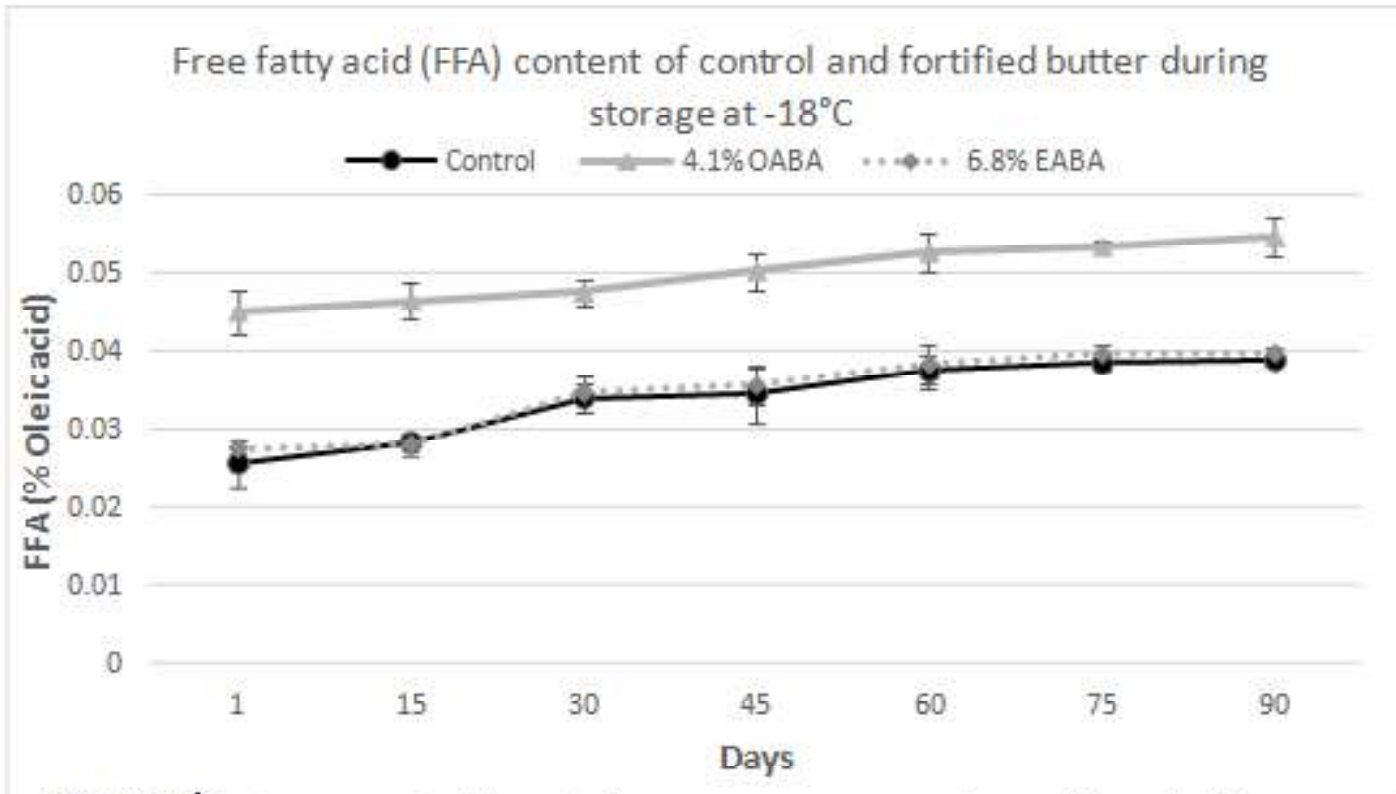

Figure 3b (OABA-Oil addition before ageing, EABA-Emulsion addition before ageing)

Fig. 3 Free fatty acid (FFA) content of control and omega- 3 fatty acid fortified butter during storage at (a) $5^{\circ} \mathrm{C}$ and (b) $-18^{\circ} \mathrm{C}$ for 90 days

(1991) are in agreement with the findings of the present study. They found increased peroxide value with the period of storage and storage at higher temperature $\left(10^{\circ} \mathrm{C}\right)$ showed significant higher value of peroxides than lower temperature storage $\left(4^{\circ} \mathrm{C}\right)$ of butter. Thus, it can be concluded that temperature and period of storage significantly affects the peroxide value of butter i.e. oxidative stability. However, the values were within the acceptable limits and didn't adversely affect the sensory acceptability of the product.
Free fatty acids (FFA) of control and fortified butter during storage

Free fatty acid content is the indicator of hydrolytic rancidity. In the present study, the samples stored at $5^{\circ} \mathrm{C}$ showed significant $(\mathrm{P}<0.05)$ increase in the free fatty acid (FFA) content during the storage period (Figure 3a). Similar trend was found for samples stored at $-18^{\circ} \mathrm{C}$ (Figure $3 \mathrm{~b}$ ). The free fatty acid content of the $4.1 \%$ OABA sample was significantly $(\mathrm{P}<0.05)$ higher than control 
and $6.8 \%$ EABA over the entire storage period. This could be attributed to the elevated the unsaturated fatty acid content being prone to oxidation. However, the FFA values were within the permissible limits thereby maintaining the sensory acceptability of the product throughout the studied storage period. The FFA content of the $6.8 \%$ EABA was significantly lower than the control sample up to $45^{\text {th }}$ day of storage and then increased non significantly $(p>0.05)$ throughout the period of storage. However, there was non-significant $(\mathrm{p}>0.05)$ difference in the FFA content of control and emulsion containing butter sample during storage. This is because of the protective action of WPC in the emulsion fortified butter as compared to direct flaxseed oil addition (Corrochano et al. 2018). The results of the present study are similar to those reported by Devdhara et al. (1991). They found increased FFA content with the period of storage and at higher temperature $\left(10^{\circ} \mathrm{C}\right)$ than lower temperature storage $\left(4^{\circ} \mathrm{C}\right)$.

\section{Thiobarbituric acid value (TBA Value) of control and fortified butter during storage}

TBA value is also an indicator of oxidative rancidity. The secondary oxidation of polyunsaturated fatty acids results into the formation of malonaldehyde (MDA). The MDA reacts with the two molecules of TBA reagent forming a red coloured compound which can be quantified using spectrophotometer. In the present study, TBA value of the samples stored at $5^{\circ} \mathrm{C}$ increased significantly $(\mathrm{P}<0.05)$ over a period of storage (Table 1). The sample $4.1 \%$ OABA showed significantly $(\mathrm{P}<0.05)$ highest and control significantly $(\mathrm{P}<0.05)$ lowest $\mathrm{TBA}$ value among the three samples. This trend was similar for the butter samples stored at $-18^{\circ} \mathrm{C}$ (Table 1). At both the temperatures, increase in TBA value was observed but at $-18^{\circ} \mathrm{C}$ storage temperature, the extent of increase was lesser than $5^{\circ} \mathrm{C}$. In the present study, increased level of unsaturated fatty acids leads to increase in TBA value throughout the storage. But the levels of TBA were within the maximum limits throughout the storage period thereby maintaining the acceptability of the butter samples.

\section{Textural properties of control and fortified butter during storage}

Texture is one of the important parameters from consumer acceptability point of view. In case of butter, spreadability is of paramount significance. In the spreadability test, the firmness and work of shear of the control butter stored at $5^{\circ} \mathrm{C}$ increased significantly $(\mathrm{P}<0.05)$ throughout the storage period. The firmness and work of shear of the sample prepared from addition of flaxseed oil $(4.1 \%$ OABA) showed significant $(\mathrm{P}<0.05)$ increase during the storage period. Similarly, sample made using flaxseed oilWPC emulsion $(6.8 \%$ EABA) showed significant $(\mathrm{P}<0.05)$ increment in the firmness and work of shear over a period of storage. Among the samples stored at $5^{\circ} \mathrm{C}$, control butter showed significantly $(\mathrm{P}<0.05)$ highest, while the sample prepared using emulsion lowest firmness and work of shear throughout the storage period (Table 2a). This is attributed to the higher unsaturated fats present in the fortified butter sample. Similarly, the stickiness and work of adhesion of the butter samples also increased significantly $(\mathrm{P}<0.05)$ over the storage period (Table $2 \mathrm{~b})$. Control sample had highest $(\mathrm{P}<0.05)$ and $6.8 \%$ EABA had lowest $(\mathrm{P}<0.05)$ value of stickiness and work of adhesion.

In case of butter samples stored at $-18^{\circ} \mathrm{C}$, there was significant increase in all the textural properties studied i.e. firmness, work of shear, stickiness and work of adhesion throughout the storage period. Control butter had significantly $(\mathrm{P}<0.05)$ higher and $6.8 \%$ EABA had lower values of textural properties (Table $2 \mathrm{a}$ and $\mathrm{b}$ ), thereby making the latter more spreadable. But storage at $-18^{\circ} \mathrm{C}$ showed higher values of textural properties than $5^{\circ} \mathrm{C}$ storage. This could be attributed to the presence of more solid fat in the butter samples at sub-zero temperature, thereby leading to increase in firmness, work of shear, stickiness and work of adhesion as compared to their counterparts stored at refrigeration temperature $\left(5^{\circ} \mathrm{C}\right)$.

Creep test helps in predicting the stacking strength of the butter by providing information on yield stress and retardation time. Further, yield stress is the minimum stress required to start flow behaviour, while retardation time is the time required to recover $63 \%$ of the total deformation. The butter samples stored at $5^{\circ} \mathrm{C}$ as well as $-18^{\circ} \mathrm{C}$, exhibited a significant $(\mathrm{P}<0.05)$ increase in the yield stress throughout the period of storage (Table 3 ). Thus, it can be said that the butter samples were firmer upon storage. The control sample stored at both the temperatures showed highest $(\mathrm{P}<0.05)$ and $6.8 \%$ EABA showed lowest $(\mathrm{P}<0.05)$ yield stress, indicating higher spreadability of the emulsion fortified butter than control. These results also correlate with the increasing firmness values. The samples stored at $-18^{\circ} \mathrm{C}$ showed higher values of yield stress than $5^{\circ} \mathrm{C}$ storage due to the increased presence of solid fat at lower temperature of storage. Similarly, a significant $(\mathrm{P}<0.05)$ increase in the retardation time of the butter samples stored at both $5^{\circ} \mathrm{C}$ and $-18^{\circ} \mathrm{C}$ (Table 3 ). Similar to yield stress, control butter showed highest and $6.8 \%$ EABA showed lower retardation time at both the temperature.

The samples stored at $-18^{\circ} \mathrm{C}$ had higher retardation time than $5^{\circ} \mathrm{C}$. Similar studies have been reported by Schaap et al. (1981) for increase in the firmness of butter up to 21 days when stored at $15^{\circ} \mathrm{C}$ for 40 days. Nabar et al. (1969) also observed an increase in the firmness of the butter during storage. Kulkarni and Rama Murthy, (1985) also found that maximum increase in the firmness occurs in the $1^{\text {st }}$ week of storage. Similarly, Desai et al. (1994) observed that during $1^{\text {st }}$ week of storage, firmness of butter increased drastically and later slightly throughout the storage period. 


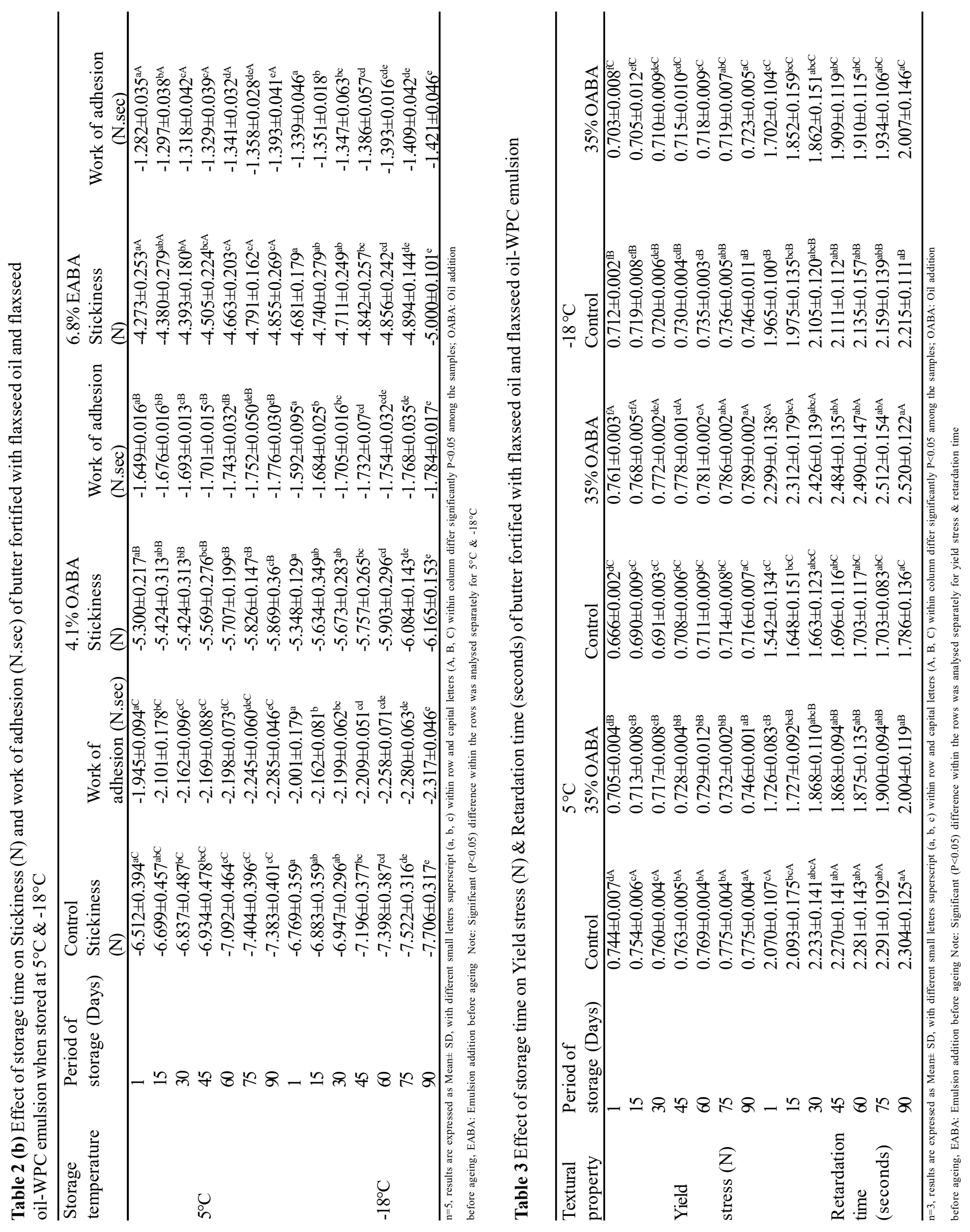


Table 4 Effect of storage time on overall sensory acceptability butter fortified with flaxseed oil and flaxseed oil-WPC emulsion when stored at $5^{\circ} \mathrm{C} \&-18^{\circ} \mathrm{C}$

\begin{tabular}{lllll}
\hline Storage temperature & Period of storage (Days) & Control & $4.1 \%$ OABA & $6.8 \%$ EABA \\
\hline & 1 & $8.05 \pm 0.269^{\mathrm{aA}}$ & $7.86 \pm 0.223^{\mathrm{aB}}$ & $8.01 \pm 0.147^{\mathrm{aAB}}$ \\
& 15 & $7.94 \pm 0.263^{\mathrm{aAA}}$ & $7.81 \pm 0.264^{\mathrm{abB}}$ & $7.92 \pm 0.187^{\mathrm{abAB}}$ \\
$5^{\circ} \mathrm{C}$ & 30 & $7.89 \pm 0.284^{\mathrm{abA}}$ & $7.77 \pm 0.214^{\mathrm{abB}}$ & $7.86 \pm 0.179^{\mathrm{abAB}}$ \\
& 45 & $7.86 \pm 0.140^{\mathrm{abA}}$ & $7.74 \pm 0.170^{\mathrm{abB}}$ & $7.85 \pm 0.176^{\mathrm{abAB}}$ \\
& 60 & $7.83 \pm 0.198^{\mathrm{bA}}$ & $7.72 \pm 0.210^{\mathrm{bB}}$ & $7.85 \pm 0.142^{\mathrm{bAB}}$ \\
& 75 & $7.81 \pm 0.109^{\mathrm{bA}}$ & $7.70 \pm 0.150^{\mathrm{bB}}$ & $7.80 \pm 0.096^{\mathrm{bAB}}$ \\
& 90 & $7.77 \pm 0.140^{\mathrm{bA}}$ & $7.68 \pm 0.109^{\mathrm{bB}}$ & $7.77 \pm 0.167^{\mathrm{bAB}}$ \\
& 1 & $8.01 \pm 0.253^{\mathrm{aA}}$ & $7.94 \pm 0.170^{\mathrm{aB}}$ & $7.95 \pm 0.141^{\mathrm{aAB}}$ \\
& 15 & $7.95 \pm 0.118^{\mathrm{abA}}$ & $7.84 \pm 0.141^{\mathrm{abB}}$ & $7.88 \pm 0.145^{\mathrm{abAB}}$ \\
& 30 & $7.89 \pm 0.099^{\mathrm{bcA}}$ & $7.83 \pm 0.141^{\mathrm{bcB}}$ & $7.84 \pm 0.121^{\mathrm{bcAB}}$ \\
& 45 & $7.84 \pm 0.130^{\mathrm{bcdA}}$ & $7.81 \pm 0.165^{\mathrm{bcdB}}$ & $7.82 \pm 0.280^{\mathrm{bcdAB}}$ \\
& 60 & $7.82 \pm 0.108^{\mathrm{cdeA}}$ & $7.71 \pm 0.173^{\mathrm{cdeB}}$ & $7.77 \pm 0.225^{\mathrm{cdeAB}}$ \\
& 75 & $7.80 \pm 0.157^{\mathrm{deA}}$ & $7.68 \pm 0.213^{\mathrm{deB}}$ & $7.75 \pm 0.199^{\mathrm{deAB}}$ \\
& 90 & $7.76 \pm 0.160^{\mathrm{eA}}$ & $7.63 \pm 0.142^{\mathrm{eB}}$ & $7.69 \pm 0.104^{\mathrm{eAB}}$ \\
\hline
\end{tabular}

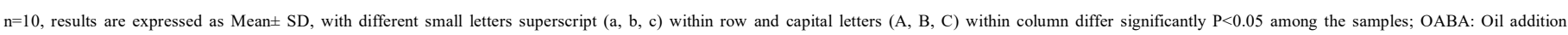
before ageing, EABA: Emulsion addition before ageing Note: Significant $(\mathrm{P}<0.05)$ difference within the rows was analysed separately for $5^{\circ} \mathrm{C} \&-18^{\circ} \mathrm{C}$

\section{Sensory characteristics of control and fortified butter during storage}

Sensory evaluation is the most significant attribute in predicting the quality of product using human sense organs. In the present study, sensory evaluation of the control and fortified samples was carried out after every 15 days of interval during 90 days storage. Overall acceptability scores of the samples stored at $5^{\circ} \mathrm{C}$ decreased significantly $(\mathrm{P}<0.05)$ during storage period (Table 4). This was because of gradual increase in perceivable flaxseed oil flavour during storage. However, the score was above 7.5 throughout the storage period indicating the likeability of the samples by the sensory panellists. The control butter had highest $(\mathrm{P}<0.05)$ and $4.1 \%$ OABA had lowest $(\mathrm{P}<0.05)$ overall acceptability score owing to the difference in fatty acid composition of both the samples. In a study conducted by Kulkarni and Rama Murthy (1985), little effect was observed in sensory quality of the butter during storage. They stored butter samples at two different $\left(4^{\circ} \mathrm{C}\right.$ and $10^{\circ} \mathrm{C}$ ) temperatures and observed the occurrence of rancid flavour by sensory analysis. Samples were stored minimum for 90 days and 105 days at $10^{\circ} \mathrm{C}$ and $4^{\circ} \mathrm{C}$, respectively. Rancid flavour in the sample (without preservative) was perceived only after 60 days and 75 days at $10^{\circ} \mathrm{C}$ and $4{ }^{\circ} \mathrm{C}$, respectively. Contrary to the findings of Kulkarni and Rama Murthy (1985), no rancid flavour was observed till 90 days of storage in control as well as fortified butter samples in the present study. The overall acceptability scores of the samples stored at $-18^{\circ} \mathrm{C}$ decreased significantly $(\mathrm{P}<0.05)$ (Table 4), but the scores were above 7.5 during the complete storage period.

\section{Alpha-linolenic acid (ALA) content of control and fortified butter during storage}

The ALA content of control $(0.872 \%)$ butter increased to $3.149 \%$ in $4.1 \% \mathrm{OABA}$ butter sample and to $3.174 \%$ in $6.8 \%$ EABA butter sample upon fortification. The highest recovery of ALA was found in butter sample prepared by addition of emulsion in cream $(6.8 \%$ EABA) owing to the binding property of WPC present in the emulsion. During 90 days of storage, the ALA content decreased in the control and fortified butter, with $0.68 \%, 3.04 \%$ and $2.33 \%$ in control, direct oil fortified and emulsion fortified butter samples, respectively. These values in the fortified samples are suitable in providing $26.6 \%$ and $20.39 \%$ recommended dietary allowance (RDA) of $\alpha$-linolenic acid through one serving of direct oil fortified and emulsion fortified butter samples, respectively even after 90 days of storage. Similar results were obtained by Gowda et al. (2018) for decrease in the $\alpha$-linolenic acid content of the omega-3 fatty acid fortified ice-cream during storage of 120 days.

\section{Microbial quality of control and fortified butter during storage}

The shelf life of butter also depends on its microbial load. There was no microbial growth i.e. coliform count as well as yeast and mould count throughout the period of storage (Table 5). According to FSSAI, the maximum limit for coliform count is 20 $\mathrm{cfu} / \mathrm{g}$ and for yeast and mould count is $50 \mathrm{cfu} / \mathrm{g}$ for butter. Thus, from the results it is concluded that the microbial quality of the product was acceptable till the end of storage period studied. Mallia et al. (2008) studied the microbial growth in the unsaturated fatty acids enriched butter and found significant increase in the lipolytic and mesophilic microorganism after 6 weeks of storage. Increased moisture content in the enriched butter than conventional butter leads to higher microbial growth. 


\section{Conclusions}

Therefore, it can be inferred that addition of flaxseed oil or flaxseed oil-whey protein concentrate emulsion in cream before ageing could be used as a suitable approach for developing omega-3 fatty acids fortified butter. The developed product is stable under both refrigeration and deep freezer conditions with acceptable sensory and textural properties. The developed butter is also acceptable in terms of oxidative stability. Further, most importantly, the alpha-linolenic acid content was higher in the butter fortified with flaxseed oil (3.149\%) as well as with emulsion (3.174\%) than control (0.86\%). Alpha-linolenic acid (ALA) content of control, oil fortified and emulsion fortified butter decreased slightly over the storage period. However, the direct oil fortified and emulsion fortified butter samples are suitable in providing $26.6 \%$ and 20.39 $\%$ RDA, respectively of $\alpha$-linolenic acid in one serving of butter. Additionally, the oxidative stability, textural properties and sensorial acceptability of fortified butter remain in the acceptable range even after 90 days of storage. Conclusively, omega-3 fatty acid fortified butter could be prepared with a shelf life of minimum 90 days using flaxseed oil as the vegetarian supplement.

\section{Acknowledgements}

The authors gratefully acknowledge Director, ICAR-National Dairy Research Institute, Karnal, India and Head, SRS, ICARNDRI, Bengaluru for financial assistance and AAK Kamani Oil Industry, Mumbai, India for gifting flaxseed oil to conduct the present study.

\section{References}

AOAC (2005) Official methods of Analysis of the Association Analytical Chemists 17 th edition Washington, D.C USA

Brenna JT, Salem Jr N, Sinclair AJ, Cunnane SC (2009) $\alpha$-Linolenic acid supplementation and conversion to n-3 long-chain polyunsaturated fatty acids in humans. Prostag Leukotr Ess 80: 85-91

Chen B, Mc Clements DJ, Decker EA (2013) Design of foods with bioactive lipids for improved health. Annu Rev Food Sci Techol 4: 35-56

Corrochano A R, Buckin V, Kelly P M, Giblin L (2018) Invited review: Whey proteins as antioxidants and promoters of cellular antioxidant pathways. J Dairy Sci 101: 4747-4761

Couedelo L, Boue-Vaysse C, Fonseca L, Montesinos E, Djoukitch S, Combe $\mathrm{N}$, Cansell M (2011) Lymphatic absorption of $\alpha$-linolenic acid in rats fed flaxseed oil-based emulsion. Brit J Nutr 105: 1026-1035

Dawczynski C, Martin L, Wagner A, Jahreis G (2010) n-3 LC-PUFAenriched dairy products are able to reduce cardiovascular risk factors: a double-blind, cross-over study. Clin Nutr 29: 592-99

Desai NB, Thaker PN, Prajapati PS (1994) Rheology of commercial table butter determined with cone penetrometer. Indian J Dairy Sci 47: 352-352

Devdhara VD, Murthi TN, Punjrath JS, Aneja RP (1991) Low-calorie butter spreads from cream: Part I. Manufacture, physical properties and keeping quality. Indian J Dairy Sci 44: 111-115

Drouin G, Catheline D, Sinquin A, Baudry C, Le Ruyet P, Rioux V, Legrand $P$ (2018) Incorporation of dairy lipids in the diet increased longchain Omega-3 fatty acids status in post-weaning rats. Front Nutr 5
FAO/WHO (2010) Fats and Fatty Acids in Human Nutrition Rome: FAO Food and nutrition paper \# 69791 Report of an expert consultation Geneva, November 10-14, 2008.

Gowda A, Sharma V, Goyal A, Singh AK, Arora S (2018) Process optimization and oxidative stability of omega-3 ice cream fortified with flaxseed oil microcapsules. J Food Sci Technol 55: 1705-1715

Gruenwald J, Petzold E, Busch R, Petzold HP, Graubaum HJ (2009) Effect of glucosamine sulfate with or without omega-3 fatty acids in patients with osteoarthritis. Adv Ther 26: 858

Indian standards, IS:3507-1966. Methods for sampling and test for butter. Indian Standard Institution, New Delhi, India.

Kolanowski W, Jaworska D, Wei Xbrodt J (2007) Importance of instrumental and sensory analysis in the assessment of oxidative deterioration of omega-3 LC PUFA-rich foods. J Sci Food Agr 87: $181-191$

Kulkarni S, Ramamurthy MK (1985) Studies on changes in rheological characteristics of butter stored at different temperature for different periods. Indian J Dairy Sci 38:111-114

Kuruppu DP, Schmidt K, Langerak DI, Van Duren MDA, Farkas JB (1983) The effect of irradiation and fumigation on the antioxidative properties of some spices. IFFIT Report No: 37, 22.

Mallia S, Piccinali P, Rehberger B, Badertscher R, Escher F, SchlichtherleCerny H (2008) Determination of storage stability of butter enriched with unsaturated fatty acids/conjugated linoleic acids (UFA/CLA) using instrumental and sensory methods. Int Dairy J 18: 983-993

Mantzioris E, Cleland LG, Gibson RA, Neumann MA, Demasi M, James MJ (2000) Biochemical effects of a diet containing foods enriched with n" 3 fatty acids. Am J Clin Nutr 72(1): 42-48

McKenna BM, Kilcast D (2003) Using emulsifiers to improve food texture. In: Texture in Food-Semi-Solid Foods, (Vol. 1, pp. 216-250. Woodhead Publishing, England.

Mori TA, Burke V, Puddey IB, Watts GF, O’Neal DN (2000) Puriûed eicosapentaenoic and docosahexaenoicacids have differential effects on serum lipids and lipoproteins LDL particle size glucose, and insulin in mildly hyperlipidemic men. Am J Clin Nutr 71: 1085-94

Nabar AB, Srinivasan MR, Iya KK (1969) Studies on the rheological properties of butter made from buffalo cream. Indian J Dairy Sci 22:237-242

Nadeem M, Abdullah M, Hussain I, Inayat S, Javid A, Zahoor Y (2013) Antioxidant potential of Moringa oleifera leaf extract for the stabilisation of butter at refrigeration temperature. Czech J Food Sci 31: 332-339

Oomah BD, Mazza G (1998) Flaxseed products for disease prevention. In: Functional Foods: Biochemical and Processing Aspects, (pp. 91138). Mazza, G., Ed., Technomic Publishing Co, Inc., Lancaster, PA

Pandule VS, Sharma M, Devaraja, HC and B Surendra Nath (2021) Omega3 fatty acid fortified butter: Preparation and characterisation of textural, sensory, thermal and physic-chemical properties. Int J Dairy Technol 74: 181-191

Ramcharitar A, Badrie N, Mattfeldt Beman M, Matsuo H, Ridley C (2005) Consumer acceptability of muffins with flaxseed (Linum usitatissimum). J Food Sci 70: 504-507

Schaap JE, Hagedoorn HG, Rutten GAM (1981) Effect of storage time, temperature and working on the firmness and spreadability of butter. Nederlands Inst. voor Zuivelonderzoek, Ede Zuivelzicht (Netherlands) 73: 38-40

Singh KK, Mridula D, Rehal J, Barnwal P (2011a) Flaxseed: a potential source of food, feed and fiber. Crit Rev Food Sci 51: 210-222

Singh RB, Moshiri M, De Meester F, Juneja L, Muthusamy V, Manoharan $\mathrm{S}(2011 \mathrm{~b})$ The evolution of low $\omega-6 / \omega-3$ ratio dietary pattern and risk of cardiovascular diseases and diabetes. J Altern Med Res 3: 4570 